\title{
Building networks among info pros
}
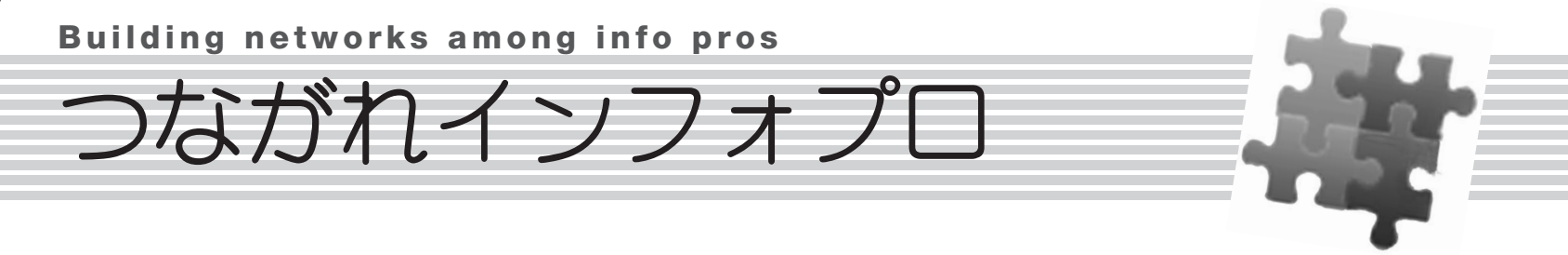

第 2 回

清田＼cjkstart陽 司（株式会社ネクストHOME'S事業本部リッテルラボラトリーユニット）

情報管理５6(8)，549-551，doi: 10.1241/johokanri.56.549 (http://dx.doi.org/10.1241/johokanri.56.549)

マイニング探検会（通称マイタン）は，図書館や 出版業界など，知識情報産業に携わるメンバーを中 心として，情報マイニングや検索，Webサービスの 技術にフォーカスして新たな図書館の未来を探るこ とを目的とした勉強会である。岡本真氏（アカデミッ ク・リソース・ガイド株式会社）と清田の両名を発 起人として2010年4月に発足し，おおむね月1回のペー スで開催している。2013年4月からは，東京と京都で の隔月開催となり，関東・関西地方を中心に，約40 名のメンバーが参加している。

マイタンの活動は，主に月例の勉強会と，不定期 に開催する合宿，図書館総合展などでの成果報告な どから成っている。月例の勉強会は，おおむね以 下の内容である。毎回の内容については，マイタ ンWebサイト1）の議事録，USTREAMによる録画や Togetterなどから見ることができる。

（1）清田による話題の紹介

図書館の情報サービスのあり方に大きな影響を与 えている商用の検索エンジンや情報推薦システムの 分野で注目されている話題についての紹介を行って いる。2013年度は，利用者の行動を把握するために 欠かせない行動心理学に関する話題にフォーカスし て紹介している。

（2）メンバーによる活動報告

メンバーがそれぞれの所属組織で行っている先進 的な取り組みや，マイタンで学んだ知識の応用事例 などについてのシェアを行っている。

\section{（3）ディスカッション}

上記の内容を受けて，メンバー同士でディスカッ
ションを行う時間を設けている。

勉強会の終了後には，毎回必ず懇親会を開くこと で，メンバー間の交流の活発化を図っている。一方， 合宿については，これまで泊まり込みで3回の合宿を 行つた。1回目の合宿は，「共生プログラミング」の 実践として，エンジニアも交えた開発合宿を神奈川 県真鶴町で2012年7月末に行った（成果についてはマ イタンのWebサイト1) に掲載しているのでご覧いた だきたい)。また，2012年9月，12月に，山中湖，京 都で企画合宿を行つた。3つのチームに分かれて新た なサービス企画をつくり，企画のブラッシュアップ を続けている。

マイタンという勉強会の特色の1つは，メンバーの 多様さにあると考えている。メンバーの大半を占め るのはライブラリアンだが, 大学図書館, 公共図書館, 専門図書館，学校図書館など，さまざまな館種の方 が参加している。また，出版社，図書館システムの

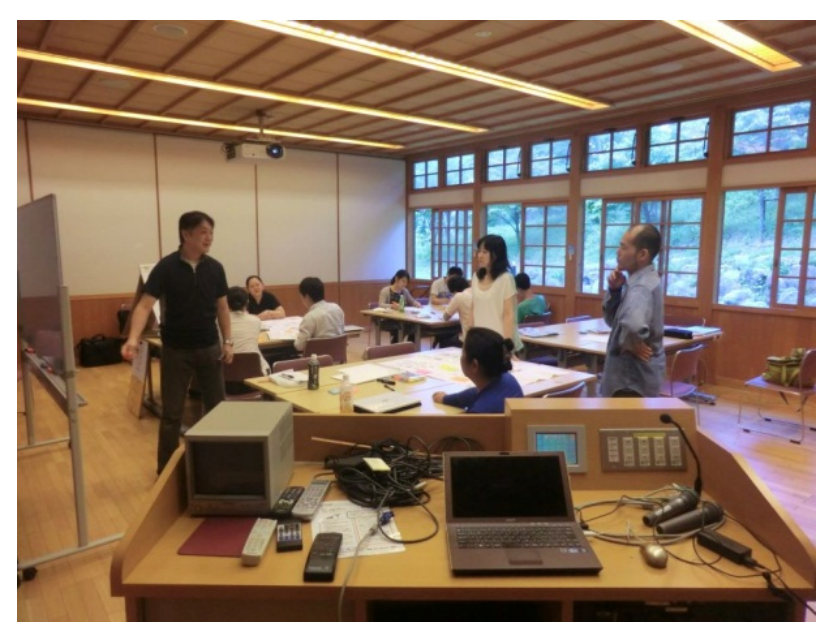

図1＼cjkstart企画合宿（2012年9月，山中湖情報創造館） 
ベンダーやベンチャー企業の方も参加している。

マイタンでは，メンバーの多様さという特徵を生 かして，組織間で個人の活動をべースとした緩やか な連携関係を構築している。それによって，現実世 界に影響を与える方向で，専門性の価值を生かすた めの新たな方法論を生み出していくことを目指した 取り組みを続けている。

ここでは，専門性をもったメンバー同士が「つな がる」ことの意味を，「組織」と「個人」という観点 から考察した上で，マイタンを運営するために行っ ている工夫について述べたい。

\section{専門性と組織}

情報を扱う専門家としての図書館員にとっても， 専門分野をもつ研究者にとっても，「この仕事で食べ ていけるかどうか」は重大な関心事であろう。「食べ ていく」源泉としての専門性を積み重ねていくため には，「専門性を発揮する」という行為を続けるしか ないが，専門性を生かし，継続できる環境をどうやっ て得るかは，専門家を志す者にとって永遠のテーマ なのかもしれない。夏目漱石による講演録『道楽と 職業』や，日比谷公園を設計した本多静六博士の『私 の財産告白』を読むと，明治時代の先人たちも，「継 続できる環境」を作る（二稼ぐ仕組みを作る）ために， 大変な苦労と，多くの工夫を重ねていたことがわか る。

私は現在，情報ナビゲーションシステムや情報推 薦システムの研究者として，Web情報サービスを運 営する民間企業に所属し，研究開発に従事している。 専門性の発揮を継続するためには，組織に所属する ことでアクセスできる組織内の有形無形の資産は， きわめて魅力的であることを痛感する。例えば，月 あたり数百万人が利用するWebサービスのログデー タは，ユーザーの行動の裏に隠れた本質的な二ーズ を研究するための強力なツールである。しかし，継 続的に給与が支払われる仕組みが確立されているこ ともまた，組織に所属することのメリットであるこ
とは否定できない。これは，専門性を生かそうとす る職業人の多くが組織に所属する大きな理由ではな いだろうか。

一方で，専門性を「世の中の役に立てる」という ことを目指そうとするとき，所属している組織が「壁」 になってしまうことも多いように感じる。例えば， 大学の研究活動の成果を社会に還元していくことを 目指す場合には，ビジネスモデルの構築などはもち ろんのこと，民間企業などの外部組織との連携を図っ ていく必要があるが，一方で利益相反や秘密保持の 課題などをクリアしていかなければならない。また， 個々の図書館でのメタデータ整備やレファレンス事 例の集積の価值を世の中に広めていこうとすれば， 組織間での情報交換が重要になるが，組織同士で連 携関係を構築・維持するには高いコストがかかる。

組織の壁を乗り越え，専門性を生かすということ は，個人の「伝える」力の向上と切り離せない関係 にあるのではないだろうか。私自身も，専門分野で ある情報検索や情報推薦に関する技術を，専門外の メンバーの方にもできるかぎりわかりやすく伝える 工夫をする中で，多くのことを学べているように思 う。

\section{マイタン運営の工夫}

マイタンでは，メンバーそれぞれに個人として参 加していただくことを基本方針としている。ほとん どのメンバーは組織に所属しているが，マイタンと いう場では，発言の責任はあくまで個人に帰属する ものとし，合宿で作り上げた成果物についても個人 に帰属することとしている。

また，異なる組織に属するメンバ一同士でノウハ ウを共有し，ゆるやかな連携を作り出すためには， お互いに手の内をさらすことは避けては通れない。 そのために，勉強会へのフリーライダーを生まない ための運営方針を堅持し，メンバーの方には勉強会 運営への明確なコミットメント（関与）を求めてい る。メンバー間の連絡や出欠管理はFacebookグルー 
プを利用しているが，月例の勉強会には必ず出欠の 表明をしていただくようにお願いしている。また， 議事録作成や懇親会会場の予約などをメンバーの持 ち回りで担当していただいたり，USTREAM中継など の運用にかかる費用として，年あたり数千円の会費 の負担をお願いしたりしている。これらの方針は， 参加のハードルを高くしてしまうデメリットはある が，「組織の壁を乗り越えて，新たな価值を創り出す」 という目的のためにはやむをえないと考えている。

おわりに

ここでは，マイタンという勉強会で行っている取 り組みと，その背景にある運営の考え方について紹 介した。これまで，合宿なども含めると40回以上の 集まりを継続してきているが，運営のコストは必ず しも小さくはない。それにもかかわらず継続できて いるのは，Facebookグループの活用などによって コミュニケーションのコストを下げる工夫を行って いることもあるが，活発に自らの活動内容をシェア していただいているメンバーの方々の熱意に支えら れているからではないかと考えている。中には，青 森県などの遠方から参加している方々もいらっしゃ る。多大な時間と費用を投資して参加している理由 には，自らの専門性を磨くための投資という考え方 があるように感じている。

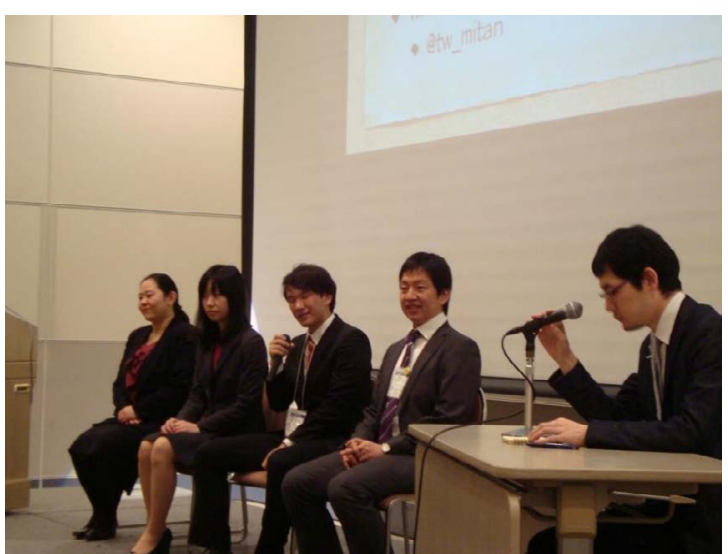

図2 第14回図書館総合展での成果報告フォーラム (2012年11月，パシフィコ横浜)

マイタンの活動についてはFacebookページ2)や Twitter（ハッシュタグ \#mitan）などを通じて発信 しているので, フォローしていただけると幸いであ る。また，新たに参加を検討されている方は清田ま たは岡本氏まで個人的に連絡をいただきたい。

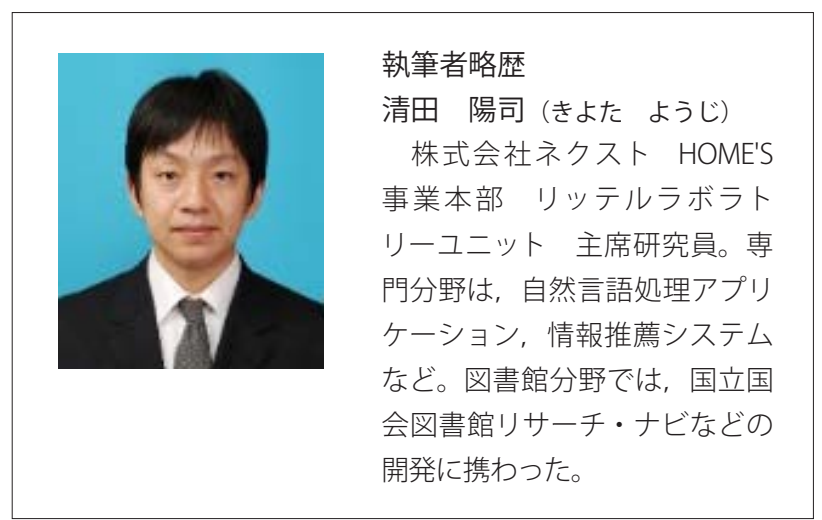

\section{引用文献}

1) マイニング探検会. http://www.mi-tan.jp, (accessed 2013-09-24).

2) Facebookマイニング探検会. https://www.facebook.com/MiningExploration, (accessed 2013-09-24). 